\title{
Memories Are Made of This: Rainer Werner Fassbinder's Veronika Voss
}

ROBERT J. CARDULLO

University of Michigan

\begin{abstract}
This article is a re-viewing of Veronika Voss in the context of global cinema, German cinema, and R. W. Fassbinder's oeuvre, in particular the FRG trilogy (on Germany's postwar economic miracle) of which this film forms a part along with The Marriage of Maria Braun and Lola.
\end{abstract}

Keywords: R. W. Fassbinder, Veronika Voss, FRG trilogy, German film.

\section{Resumen}

Este artículo es una revisión de Veronika Voss en el contexto del cine global, del cine alemán y de la obra de R.W. Fassbinder, en particular de la trilogía FRG (sobre el milagro económico de la posguerra de Alemania) de la cual esta película forma parte junto con El matrimonio de María Braun y Lola.

Palabras clave: R.W. Fassbinder, Veronika Voss, Trilogía FRG, cine alemán

\section{Fassbinder in Context}

Perhaps in ironic reference to the sentimental, idyllic postwar genre of the Heimatfilm (homeland film), Rainer Werner Fassbinder once said, famously, that he was trying to construct a house with his films, which is hard, enervating, and even dangerous work. Many filmmakers have left their own houses half-finished. But, with the possible exception of, say, Yasujiro Ozu, Fassbinder was the only one who left a beautiful, livable dwelling into which others might enter and be inspired to build their own. Had he lived, he would surely have made modifications and built many extensions, but the fact that he left us with a finished product is fairly astonishing given the short time he had to complete it. Not every part of the house is equally interesting: think of Satan's Brew (1976) as the plumbing and Chinese Roulette (1976) as the wiring. The three films that comprise the famous FRG (Federal Republic of Germany) Trilogy, as it came to be known, are the rock-solid foundation-or, perhaps, the central staircase: The Marriage of Maria Braun (1979), Veronika Voss (1982), and Lola (1981). 
Unlike most of the other houses going up around him at the time, built with flimsy modern foundations that didn't go deep enough (for fear of hitting the rotten substratum of Nazism), Fassbinder's house was built with a sense of history. Of his generation, Fassbinder was the only director whose interest in German film history neglected neither the period of the Third Reich nor the much-disparaged 1950s. He had no fear of contact when he was giving parts to such actors as Luise Ullrich, Werner Finck, Adrian Hoven, and Barbara Valentin, whereas most of New German Cinema was busy relegating former stars to the background and making its farewell to "Papa's cinema."

Fassbinder understood that as a German in the 1970s, one had to do real historical excavation to re-create not just the images but the mental framework of the past; not merely to acknowledge historical amnesia, but to make an effort to understand how and why it manifested itself. Fassbinder once said of the traumatized German reaction to the American television miniseries,

When I see the fuss being made over Holocaust [1978], I wonder why they have to make such a fuss; have they really repressed and forgotten all of that? They can't have forgotten it; they must have had it on their minds when they were creating their new state. If a thing of so much significance could be forgotten or repressed, then something must be pretty wrong with this democracy and this new "German model" (Fassbinder, 38).

He knew, you see, that all roads led back to the gray, amoral confusion of the 1950s and the years of the Wirtschaftswunder - Germany's postwar economic miracle.

Fassbinder realized that he had to build his house quickly if it was going to have any meaning, which means that he did something almost impossible: He acted at the speed of his emotions and thoughts. He wanted and got a direct correlation between living and fiction-making. This is almost impossible in film production, where there's a lot of atrophy-inducing waiting time because of the effort, money, needed manpower, tactical and strategic difficulties, endurance tests, and care required to get a presentable image. It's no wonder, then, that he resorted to cocaine and an assortment of other drugs. Indeed, it would have been shocking if he hadn't done so.

Fassbinder's nonstop work ethic also allowed him to break through the removed, God's-eye view that comes all too often with the territory of modern cinema. He's always right there with his characters, in time, space, and spirit. "Should you sit around waiting until something's become a tradition," he once said, "or shouldn't you rather roll up your sleeves and get to work developing one?" (Fassbinder, 32). Too much time spent listening to the music of your own voice gives rise to a temptation to round everything off into a definitive statement; it gives you a sense of false confidence that you're delivering, from on high, the last word on human affairs. By building his house from the inside out, Fassbinder was essentially trying to create a whole body of German films that would stand politically and spiritually against the flood of hypocritical, unfelt cinema that had come before and that was sure to come after. He tried to bypass hazy generalities and windy formulations through sheer speed and determination, and largely succeeded. "There's a sense of process in Fassbinder, a feeling of the movie as it's being made" (389), said the American critic Manny Farber, an early champion. That sense of process, of the movie and the man behind it thinking and reacting as he went along, was there right to the end, even in the fancier and more vaunted later works like Despair (1978) and Berlin Alexanderplatz (1980). 
As a result, Fassbinder casts a long shadow. His admirers have followed his example of throwing the moral underpinning out from under their narratives, but with rare exceptions (Olivier Assayas and André Téchiné come to mind), they all lack something that Fassbinder had in abundance, and that more than counterbalanced the endless, discomfited bitching of his characters: a tender eye. Such tenderness was part of a fullness of vision, and of the way he simply looked at people, that hadn't been seen since the silent era. In a 1977 interview, Farber declared that, "If someone sits on a couch in a Fassbinder movie, it's the first time it's been sat on that way in movies, it seems to me, in a long time. It's a big person on a small couch who's uncomfortable. A woman standing in a doorway in a Fassbinder film - that's a great vision. Of someone who's uncomfortable and doesn't like it and emits a feeling of savagery. In ecstatic, hieratic lighting of the kind found in Fra Angelico" (390).

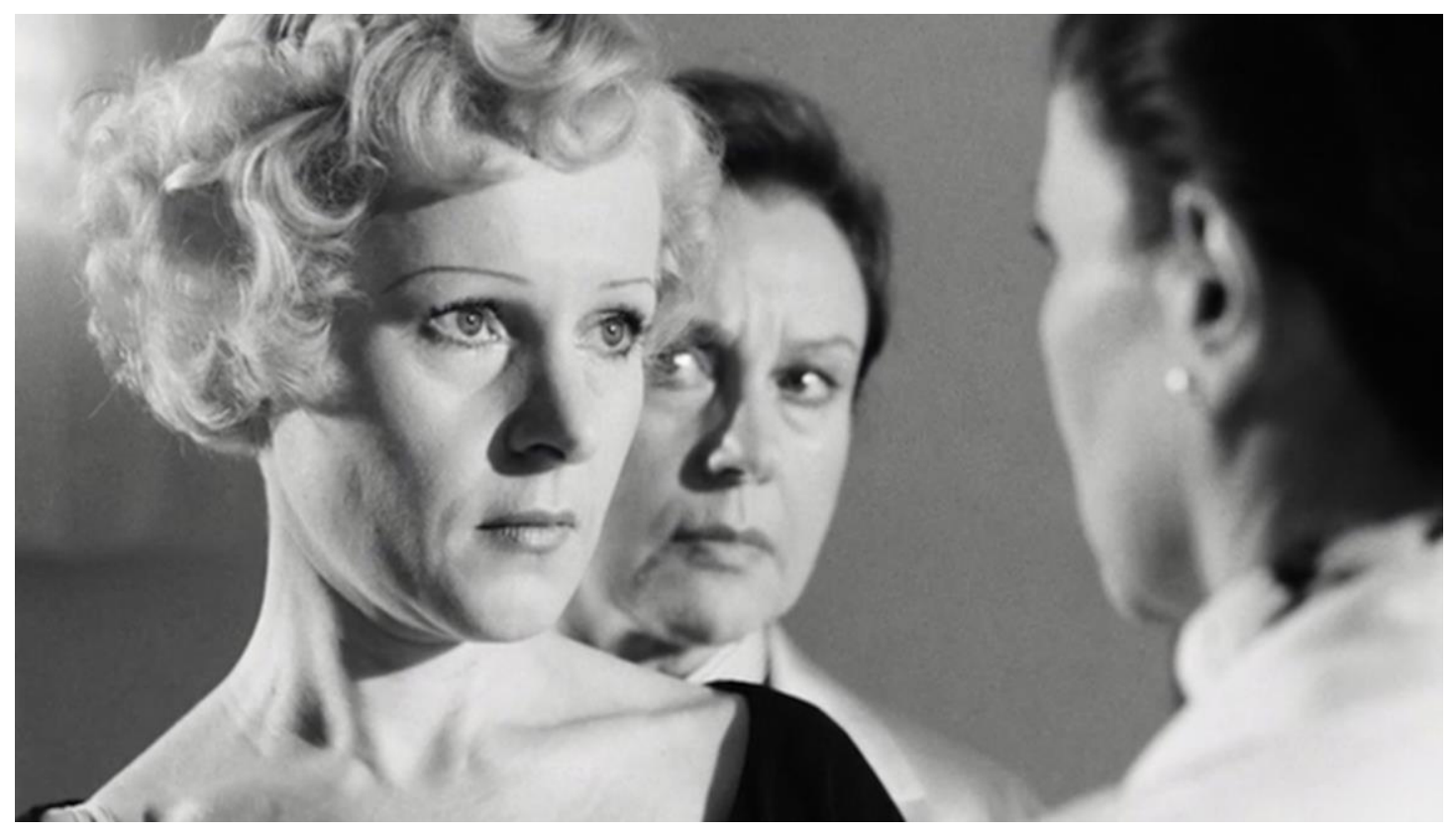

The plasticity of Fassbinder's images is almost unparalleled - in the sound era, only the work of Carl-Theodor Dreyer, Yasujiro Ozu, Robert Bresson, and Jean-Luc Godard, at its very best, has a similar force and beauty. But Fassbinder had something else, too: He was an inventor. He gave us a whole new point of view, devoid of sentimentality or even grace yet profoundly empathic. In Fassbinder, a magical world of purely human wonders is parceled out to us in the form of tales in which desperation, treachery, scheming, hypocrisy, and ignorance play no small part, and where desire plays a major supporting role but the will to power is sadly dominant. Contrary to the opinion of some, however - and it's an opinion I myself used to holdFassbinder didn't make cruel films. His dramatically blunt tales speak, with tremendous urgency, for the Maria Brauns, the Veronika Vosses, and the Lolas of this world. In one sense, then, the films are blunt instruments, but what's most important is that they give the lives of ordinary souls the care and attention they deserve. Fassbinder protected his characters from the infectious diseases of idealization and sentimentality; his filmic space is far from transcendental: there is no beyond, nor any ultimate reality. There is nothing but human relations, given an awesome intensity, elevation, and richness. No one enjoys a state of grace, but everyone is ennobled. 


\section{The FRG Trilogy and Veronika Voss}

Like a number of Fassbinder films, The Marriage of Maria Braun, Veronika Voss, and Lola describe the unconscious, collective enactment of an essentially negative action, namely the suppression of national memory, through hyperdramatic heroines whose fates are intertwined with the imperatives of their awful historical moments. How did the historical moment of the Wirtschaftswunder, of the postwar German economic miracle, come into being? Free-market boosters like to believe that it began with the installation of Ludwig Erhard, the economics minister of postwar Germany. In June 1948, when the country was at its lowest moral and economic ebb, Erhard went on the air to make two momentous announcements. The almost worthless Reichsmark would hereafter be replaced by the Deutschemark, forty of which would be distributed to every German, followed by twenty more, and followed by debt conversions at the rate of ten to one. Erhard also took the unprecedented step of dropping the wage and price controls introduced by the Nazis, first on consumer goods and, six months later, on food - a move that even the Allies hadn't considered. It's likely that Germany's recovery would have gone forward no matter what measures had been taken, since the country had nowhere to go but up. Still, a reconstruction boom took place under Erhard, and he had a lot to do with it.

Fassbinder himself was wholly uninterested in the reasons behind the miracle and more interested in the less fashionable topic of how the "miracle" narrative came into being in the first place, as well as the level of amnesia required to make it stick. In The Marriage of Maria Braun and Lola, Fassbinder saw parts of an overall picture of the FRG that help to answer these questions, as well as to better explain this strange democratic construction - its hazards and dangers, as well as its benefits and sureties. Both films, of course, feature female characters. "All sorts of things can be told better about women; men usually behave the way society expects them to," explained Fassbinder in an interview (Töteberg, Lola, n. p.). His screenwriter Peter Märthesheimer elaborated: "As far as men are concerned, it is instructive that in Lola, from a purely dramaturgical point of view, it is not Lola who is the hero, but rather Mr. von Bohm. And what are we told about our hero? That he is a victim. So the secret hero is Lola after all" (Press Guide to Lola, n. p.). The history of the FRG is told through female characters in the FRG Trilogy, which did not start out as one. Originally, Fassbinder hadn't conceived of three works on the same theme, but now he inserted, in the opening credits under the title of Lola, the subtitle "FRG 3" (FRG 3). And shortly thereafter, he supplied the missing second part of the trilogy: Veronika Voss.

Veronika Voss (FRG 2), Fassbinder's penultimate film, was based on the reallife tragedy that befell the German star Sybille Schmitz. A formidable presence during the Nazi era, Schmitz is probably best known to American audiences for her performance in Carl-Theodor Dreyer's Vampyr (1932). According to Michael Töteberg, the author of Rainer Werner Fassbinder (2002), a young Fassbinder had read the newspaper stories about Schmitz's 1955 suicide in Munich and the sensational trial of her physician, Dr. Ursula Moritz, which followed (Töteberg, Rainer Werner Fassbinder, 124-125). Dr. Moritz was charged with transgressing drug laws with the intent to gain illicit financial advantage.

Henriette von Speidel, a seventy-year-old actress, had set the ball rolling. The elderly woman had noticed that in recent years two other patients (and subtenants) of the doctor had apparently taken their own lives. She rented a room in Dr. Moritz's home and was finally able to produce the evidence: A total of 723 prescriptions for 
narcotics, made out in just under three years. Paul Demmler, an official from the Munich Health Department who was called in on the case, surprisingly defended the accused physician, and the court was not able to establish legally binding proof of a connection between the doctor's practice of prescribing narcotics and Sybille Schmitz's death. But the tabloids could not accept the verdict (Moritz was sentenced to just four months in prison), and the public learned that for months the police and the Health Department had refused to investigate the charges. The case was never satisfactorily solved, therefore leaving room for speculation.

Fassbinder and his writers changed the names and employed another vintage Hollywood scenario, that of the reporter who becomes fascinated and then consumed with the life of the person he's investigating - think only of Citizen Kane (1941). Fassbinder decided to shoot the film in late 1981, as he was preparing Kokain, a vastly more complex undertaking. The Longing of Veronika Voss, shortened simply to Veronika Voss in English, went into production as an interim project, featuring Rosel Zech in her second Fassbinder film. FRG 2 would be Fassbinder's first film in black and white since Effi Briest; it would also be his last great work, and the final chapter in one of his most sustained achievements, historically and politically, as well as aesthetically.

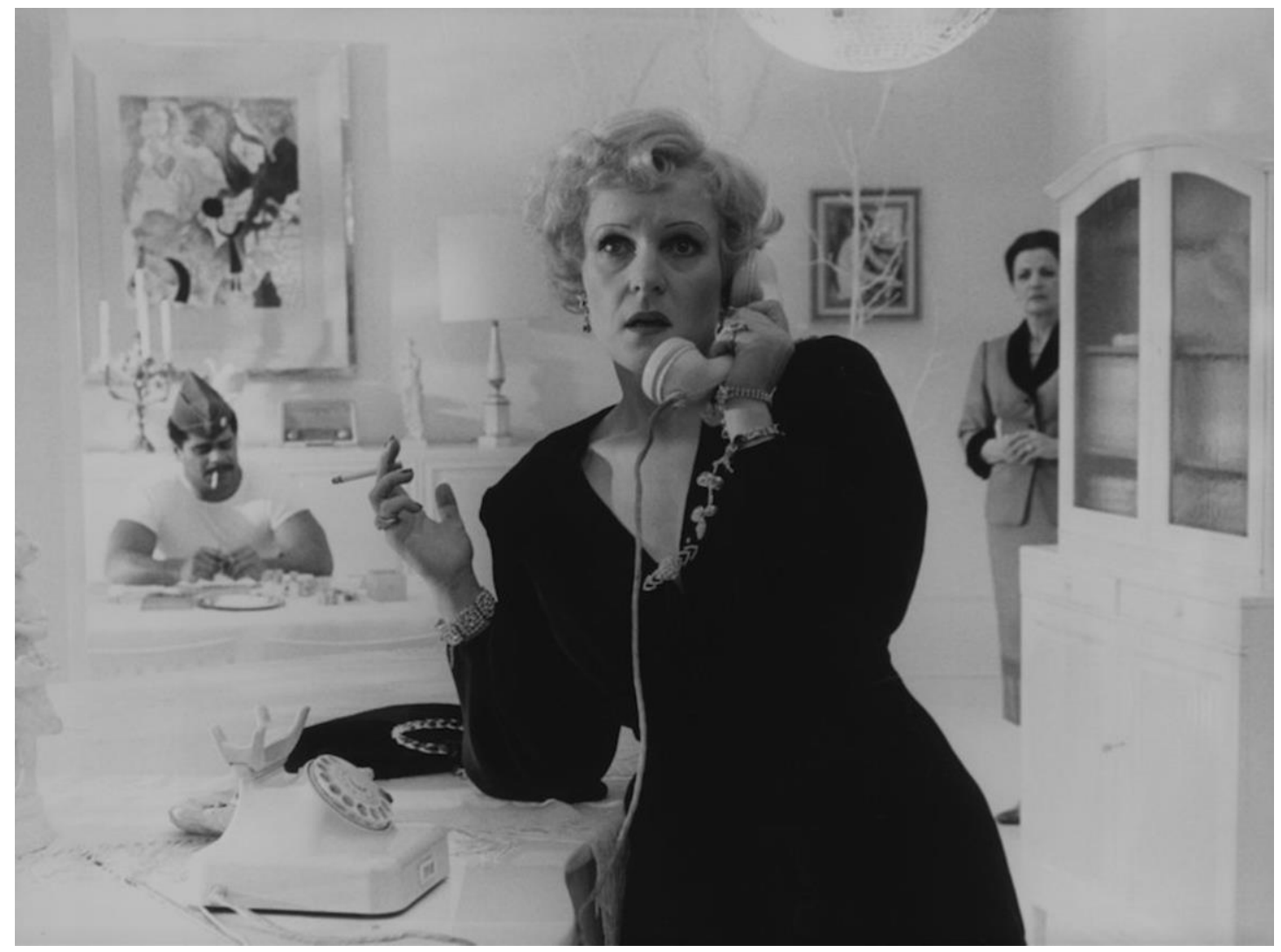

Fassbinder was thinking of a "very austere, classical narrative film" (quoted in Töteberg, Veronika Voss, n. p.), and, to this end, his scenarists Märthesheimer and Pea Fröhlich provided him with the perfect starting point. The exposition itself is a perfect example of narrative economy. Veronika Voss (Rosel Zech) is sitting in the cinema (the spectator next to her is Rainer Werner Fassbinder) watching one of her old films, a melodrama called Insidious Poison, a look back into her past but also into the future. This scene is followed without further ado by one in which she meets the journalist Robert Krohn. Her conspicuous behavior - the grotesque incongruity between the airs 
and affectations of a star and the complete disregard with which she is met by an indifferent public - is immediately evident in the streetcar. Krohn is fascinated by the woman, although the name Veronika Voss means nothing to him. He has no memories of or interest in the cinema; he is at home on the playing field. But he is a man in midlife crisis, and life for him seems dull and monotonous. Fassbinder makes Krohn into the composer of strange poems that express his feelings of deficiency. "I was fine glass spheres, devoid of foliage or prospect," is one of his verses.

Set in 1955, Veronika Voss is the middle part of the trilogy on Germany's economic miracle. Contemporary history, to a lesser degree than in the other two parts, is present here in barely perceptible snatches of radio broadcasts (a commentary by Thilo Koch about the North Atlantic Treaty Organization; a soccer game covered by sportscaster Sammy Drechsel, in which Bayern München loses) or in posters against rearmament. Recent German history, considering the way in which the Nazi period was being rewritten in the 1950s, was still traumatic for society. And as different as their fates might be, both patients of Dr. Marianne Katz (Annemarie Düringer) are victims of their own pasts: Voss and Mr. Treibel (Rudolf Platte), UFA and Treblinka, propaganda and destruction - the two primary industries of fascism.

Fassbinder and his composer, Peer Raben, gave the film music that was different from the kind originally prescribed in the screenplay. The movie begins with a glorious overture signaling high drama, but American sounds are at least as audibly present as the reminiscences of illustrative music from German film classics. Instead of Zarah Leander's "Ich weiss, es wird einmal ein Wunder geschehen" ("I Know That a Miracle Will Yet Occur"), which was called for in the screenplay, Voss sings a song Dean Martin made famous - "Memories Are Made of This" - at her big farewell party.

Fassbinder, who otherwise made only minor changes and rearrangements and shortened the openings or closings of the scenes, gave the ending a different accent altogether. A scene could still be found in the rough cut in which Voss puts up a fight, scribbles "Help!" on a scrap of paper, and desperately climbs up on a bench to get to the window, but the child across the way only stares back at her blankly. Fassbinder eliminated the scene entirely because it endangered the necessary ambivalence. This is a murder, but Veronika Voss is the "accomplice of her murderer," according to Märthesheimer (Töteberg, Veronika Voss, n. p.). In a match action cut, Fassbinder jumps from Voss as she takes the sleeping pills with a glass of water to Krohn in the newspaper office taking aspirin. He then radically shortened the final scene. In the screenplay ending, a popular hit can be heard coming from the radio in the taxi with the following lyrics, translated here from German: "Forget about the big wishes / There's no sense in that / Forget about the stars in heaven / That's where they belong." When Krohn hears this, he shouts: "Turn it off! Turn it off immediately!" The film ends without this outburst. Krohn gets into the taxi and says, "Back to Munich, to the 1860 Stadium." End of movie. There is no need for anything else: Voss is dead, and this man will never in his life be concerned with anything except sports, anyway.

"Light and shadow, those are the secrets of the cinema," says Voss. A film in black and white, the "most beautiful colors in cinema," said Fassbinder at a press conference (Töteberg, Veronika Voss, n. p.). He and his cameraman, Xaver Schwarzenberger, evoke a past cinematic art whose tradition reaches back to silent film (to repeat, Sybille Schmitz played one of her first parts in Dreyer's Vampyr), where it developed aesthetic codes of a high standard. The Cabinet of Caligari (1920) cast a long shadow: German lighting brought emigrants to Hollywood, where it placed its mark on the visual style of American film noir. In turn, Veronika Voss was Fassbinder's own version of Austrian-born Billy Wilder's Sunset Boulevard (1950). 
But genre conventions in the case of Veronika Voss are ironically disjointed, as the play of light and shadow is shuffled anew. With Fassbinder, danger reigns when the scenery is mercilessly bright and fully lit; snow-white, cold, and clinical are the rooms in Dr. Katz's practice and the room where Voss is locked up. Warmth for this auteur comes when darkness casts its shadows. The first thing of which Voss herself makes sure is that she appears in the right light — or dark. She likes candles most of all, and special lenses used by Schwarzenberger make them sparkle like diamonds.

Veronika Voss premiered in competition at the Berlin International Film Festival in 1982, and at the awards ceremony, Fassbinder experienced a triumph that had been denied him for Effi Briest and The Marriage of Maria Braun: He was awarded the Golden Bear. Fassbinder was no longer interested in victories, however. In the press booklet, the filmmaker addresses the question of whether he loved such failed figures as Veronika Voss: "I have a tender feeling toward her-I understand her in all the things she did wrong. She let herself be destroyed. Maybe that has something to do with me. You say to yourself, Okay, don't let yourself be wrecked like that, but still, it could happen to me. There are people who are just waiting for me to collapse" (Press Guide to Veronika Voss, n. p.).

\section{The End}

Tellingly, Veronika Voss was the last film Fassbinder was able to complete. His next project was to have been a film about Rosa Luxemburg. But in the early morning hours of June 10, 1982 - he had just made some notes on the treatment by Märthesheimer and Fröhlich-Rainer Werner Fassbinder died.

\section{Bibliography and Works Cited}

Barnett, David. Rainer Werner Fassbinder and the German Theatre. New York: Cambridge University Press, 2005.

Braad Thomsen, Christian. Fassbinder: The Life and Work of a Provocative Genius. Trans. Martin Chalmers. London: Faber and Faber, 1997.

Corrigan, Timothy. New German Film: The Displaced Image. 1983. Austin: University of Texas Press, 1994.

Elsaesser, Thomas. Fassbinder's Germany: History, Identity, Subject. Amsterdam: Amsterdam University Press, 1996.

--------. New German Cinema: A History. New Brunswick, N.J.: Rutgers University Press, 1989.

Farber, Manny. Negative Space: Manny Farber on the Movies. 1971. New York: Da Capo, 1998.

Fassbinder, Rainer Werner. The Anarchy of the Imagination: Interviews, Essays, Notes. Ed. Michael Töteberg and Leo Lensing. Trans. Krishna Winston. Baltimore, Md.: Johns Hopkins University Press, 1992.

Franklin, James. New German Cinema: A History. Boston: Twayne, 1983.

Hayman, Ronald. Fassbinder: Film Maker. New York: Simon and Schuster, 1984.

Kaes, Anton. From Hitler to Heimat: The Return of History as Film. Cambridge, Mass.: Harvard University Press, 1989.

Kardish, Laurence, ed. Rainer Werner Fassbinder. 1997. New York: The Museum of Modern Art/Harry N. Abrams, 2002. 
Katz, Robert, and Peter Berling. Love is Colder Than Death: The Life and Times of Rainer Werner Fassbinder. New York: Random House, 1987.

Lorenz, Juliane, et al., eds. Chaos as Usual: Conversations about Rainer Werner Fassbinder. Trans. Christa Armstrong and Maria Pelikan. New York: Applause Books, 1997.

Press Guide to Lola. Berlin: Kinowelt/Studiocanal, 1981.

Press Guide to Veronika Voss. Berlin: Kinowelt/Studiocanal, 1982.

Peucker, Brigitte, ed. A Companion to Rainer Werner Fassbinder. Malden, Mass.: Wiley-Blackwell, 2012.

Rayns, Tony, ed. Fassbinder. 1976. London: British Film Institute, 1980.

Shattuc, Jane. Television, Tabloids, and Tears: Fassbinder and Popular Culture. Minneapolis: University of Minnesota Press, 1995.

Töteberg, Michael. Rainer Werner Fassbinder. Reinbek, Gny.: Rowohlt, 2002.

--------. "The Candy-Colored Amorality of the Fifties." In production booklet for the Criterion DVD of Lola issued in 2003. n. p.

--------. "Sweet Death." In production booklet for the Criterion DVD of Veronika Voss issued in 2003. n. p.

Watson, Wallace Steadman. Understanding Rainer Werner Fassbinder: Film as Private and Public Art. Columbia: University of South Carolina Press, 1996.

\section{Veronika Voss (FRG 2, 1982)}

Director: Rainer Werner Fassbinder

Screenplay: Peter Märthesheimer, Pea Fröhlich, and Rainer Werner Fassbinder

Cinematographer: Xaver Schwarzenberger

Editor: Juliane Lorenz

Music: Peer Raben

Production Designer: Rolf Zehetbauer

Costume Designer: Barbara Baum

Running time: 104 minutes

Format: $35 \mathrm{~mm}$, in black and white

Cast: Rosel Zech (Veronika Voss), Hilmar Thate (Robert Krohn), Cornelia Froboess (Henriette), Annemarie Düringer (Dr. Marianne Katz), Armin Mueller-Stahl (Max Rehbein), Doris Schade (Josefa), Erik Schumann (Dr. Edel)

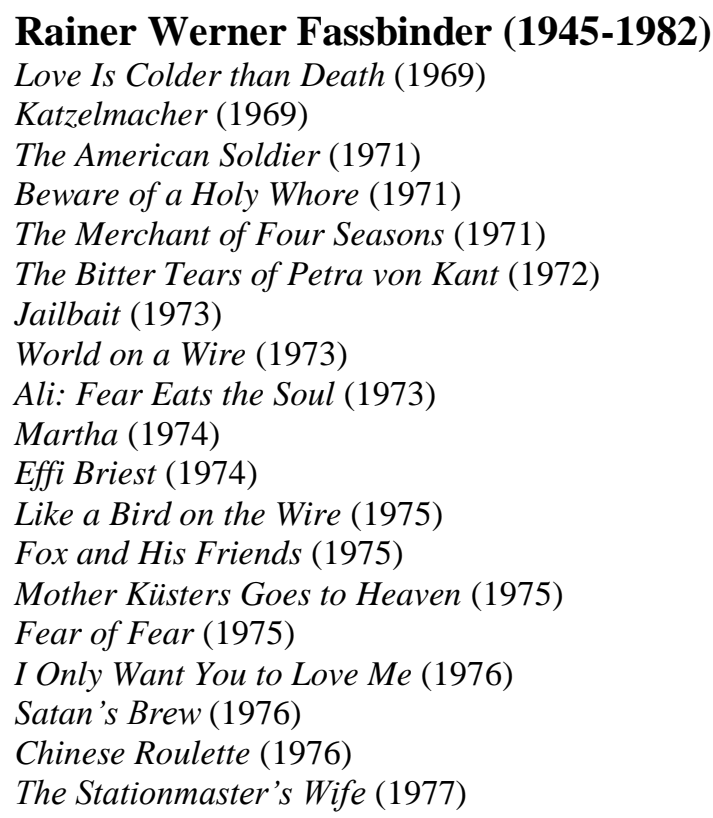




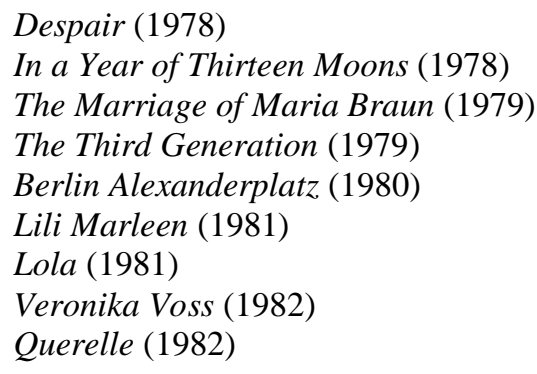

\section{Keys Films of the New German Cinema}

Machorka-Muff, dir. Jean-Marie Straub \& Danièle Huillet (1963)

Yesterday Girl, dir. Alexander Kluge (1966)

Young Törless, dir. Volker Schlöndorff (1966)

Table for Love, dir. Edgar Reitz (1967)

Artists Under the Big Top: Perplexed, dir. Alexander Kluge (1968)

Signs of Life, dir. Werner Herzog (1968)

Hunting Scenes from Bavaria, dir. Peter Fleischmann (1969)

Red Sun, dir. Rudolf Thome (1970)

Aguirre, the Wrath of God, dir. Werner Herzog (1972)

The Goalie's Anxiety at the Penalty Kick, dir. Wim Wenders (1972)

The Bitter Tears of Petra von Kant, dir. Rainer Werner Fassbinder (1972)

Dream City, dir. Johannes Schaaf (1973)

Alice in the Cities, dir. Wim Wenders (1974)

Ali: Fear Eats the Soul, dir. Rainer Werner Fassbinder (1974)

The Enigma of Kaspar Hauser, dir. Werner Herzog (1974)

The Lost Honor of Katharina Blum, dir. Volker Schlöndorff \& Margarethe von Trotta (1975)

Wrong Move, dir. Wim Wenders (1975)

Fox and His Friends, dir. Rainer Werner Fassbinder (1975)

Kings of the Road, dir. Wim Wenders (1976)

Heart of Glass, dir. Werner Herzog (1976)

Hitler: A Film from Germany, dir. Hans-Jürgen Syberberg (1977)

Stroszek, dir. Werner Herzog (1977)

The American Friend, dir. Wim Wenders (1977)

The Left-Handed Woman, dir. Peter Handke (1978)

In a Year with Thirteen Moons, dir. Rainer Werner Fassbinder (1978)

Knife in the Head, dir. Reinhard Hauff (1978)

The Tin Drum, dir. Volker Schlöndorff (1979)

Nosferatu the Vampyre, dir. Werner Herzog (1979)

Sisters, or The Balance of Happiness, dir. Margarethe von Trotta (1979)

Berlin Alexanderplatz, dir. Rainer Werner Fassbinder (1980)

Woyzeck, dir. Werner Herzog (1979)

The Marriage of Maria Braun, dir. Rainer Werner Fassbinder (1979)

Mariane and Julianne, dir. Margarethe von Trotta (1981)

Fitzcarraldo, dir. Werner Herzog (1982)

The State of Things, dir. Wim Wenders (1982)

R. J. CARDULLO has had his work appear in such journals as the Yale Review, Cambridge Quarterly, Film Quarterly, and Cinema Journal. For twenty years, from 1987 to 2007, he was the regular film critic for the Hudson Review in New York. Cardullo is the author or editor of a number of books, including Soundings on Cinema: Speaking to Film and Film Artists (SUNY Press, 2008) and In Search of Cinema: Writings on International Film Art (McGill-Queens UP, 2004). He is also the chief American translator of the film criticism of the Frenchman André Bazin. Cardullo's own film criticism has been translated into the following languages: Russian, German, Chinese, Turkish, Spanish, Korean, and Romanian. Cardullo earned his doctoral degree from Yale University and received his B.A. from the University of Florida. He taught for four decades at the University of Michigan, Colgate, and New York University, as well as abroad.

email— robertjcardullo@gmail.com 
FILMHISTORIA Online Vol. 29, núms. 1-2 (2019) · ISSN: 2014-668X 